\title{
PENGARUH KOMPETENSI DOSEN TAMU MATA KULIAH PPH OP TERHADAP KEPUASAN MAHASISWA
}

\author{
N. Purnomolastu \\ Program Studi Perpajakan Politeknik Ubaya \\ Jalan Ngagel Jaya Selatan 169, Surabaya \\ D. Tialurra Della Nabila \\ Program Studi Perpajakan Politeknik Ubaya \\ Jalan Ngagel Jaya Selatan 169, Surabaya
}

\begin{abstract}
One of the most critical objectives in all institutions of higher learning is attaining student satisfaction because student satisfaction has become an increasingly important component of institutional reports as a means of accountability to educational stakeholders. The aims of this study is to determine the influence of guest lecturer competence of PPh OP toward students' satisfaction at Prodi Perpajakan Politeknik Ubaya. The finding shows that the competence of guest lecturer is significantly relates to student satisfaction positively.
\end{abstract}

\begin{abstract}
ABSTRAK
Salah satu tujuan terpenting pada semua institusi pendidikan tinggi adalah mencapai kepuasan mahasiswa sebab kepuasan mahasiswa telah menjadi komponen yang semakin penting dari laporan kelembagaan sebagai sarana akuntabilitas kepada pemangku kepentingan pendidikan. Tujuan dari penelitian ini adalah untuk mengetahui pengaruh kompetensi dosen tamu PPh OP terhadap kepuasan mahasiswa di Prodi Perpajakan Politeknik Ubaya. Temuan menunjukkan bahwa kompetensi dosen tamu secara signifikan berhubungan dengan kepuasan mahasiswa secara positif.
\end{abstract}

Keywords: guest lecturer competence, students' satisfaction.

\section{PENDAHULUAN}

Setiap warga negara Indonesia memiliki hak dasar yang sama, salah satunya adalah berhak untuk mendapatkan pendidikan. Pendidikan tinggi adalah pendidikan setelah pendidikan menengah yang diselenggarakan oleh perguruan tinggi yang menyelenggarakan Tri Dharma Perguruan Tinggi, meliputi pendidikan, penelitian dan pengabdian pada masyarakat. Perguruan tinggi bertujuan menyiapkan peserta didik untuk memiliki kemampuan akademik dan profesional serta sebagai pengembang 
dan penyebarluas ilmu pengetahuan sehingga dapat meningkatkan taraf kehidupan masyarakat.

Setiap perguruan tinggi memiliki kesatuan kegiatan pendidikan dan pembelajaran yang disebut dengan program studi. Program Studi Perpajakan merupakan salah satu kesatuan kegiatan pendidikan dan pembelajaran di Politeknik Ubaya yang memiliki kurikulum dan metode pembelajaran dalam pendidikan vokasi di bidang perpajakan.

Program Studi Perpajakan mengusung visi menjadi program studi yang berkomitmen dalam menciptakan tenaga ahli di bidang pajak berdasarkan profesionalisme, moral dan disiplin. Visi Program Studi Perpajakan tersebut kini didukung oleh PMK No. 111 tahun 2014 tentang Konsultan Pajak yang akan berlaku tanggal 9 Desember 2014 nanti. PMK ini diantaranya menjelaskan bahwa untuk mengikuti Ujian Sertifikasi Konsultan Pajak (USKP) tingkat A wajib memiliki ijazah paling rendah D-III program studi akuntansi ataupun program studi perpajakan, peraturan ini mengubah peraturan lama dimana peserta USKP minimal memiliki ijazah Strata 1 (S-1). Dengan dikeluarkannya PMK ini, Program Studi Perpajakan semakin fokus pada visinya sehingga mahasiswa semakin matang dan siap untuk menghadapi dunia kerja dan mengikuti USKP tingkat A bagi yang berminat.

Dalam mencapai visinya, Program Studi Perpajakan memiliki beberapa misi yang salah satunya adalah menyelenggarakan pendidikan untuk menciptakan tenaga profesional di bidang pajak dengan dukungan dari berbagai pihak. Banyaknya MoU yang telah disepakati oleh berbagai pihak penting di negeri ini merupakan bukti nyata keseriusan Program Studi Perpajakan dalam melaksanakan misinya. Ikatan Konsultan Pajak Indonesia (IKPI) merupakan salah satu mitra Program Studi Perpajakan dalam bidang pendidikan dan pengabdian pada masyarakat. IKPI juga turut serta dalam memberikan masukan untuk penyusunan renstra dan kurikulum Program Studi Perpajakan.

Dalam bidang pendidikan, IKPI sebagai asosiasi konsultan pajak bersertifikat turut berpartisipasi dalam kegiatan pengajaran di Program Studi Perpajakan, yaitu sebagai dosen tamu mata kuliah pajak. Dengan diselenggarakannya kuliah dosen tamu, selain sebagai bentuk pemberian pelayanan pendidikan yang terbaik kepada mahasiswanya, Program Studi Perpajakan juga mengharapkan para mahasiswa untuk dapat menyerap ilmu perpajakan lebih luas karena diperoleh dari berbagai pihak, baik akademisi maupun praktisi. Pada setiap tahunnya Program Studi Perpajakan mengundang 12 orang dosen tamu yang sebagian besar merupakan anggota IKPI.

Pajak Penghasilan Orang Pribadi (PPh OP) merupakan mata kuliah inti di Program Studi Perpajakan untuk mahasiswa semester 2 yang membahas mengenai pengenaan pajak penghasilan terhadap wajib pajak orang pribadi di Indonesia. Dalam mata kuliah ini, mahasiswa diajarkan tentang subjek dan objek pajak sampai dengan cara mengisi SPT 1770, 1770 S dan 1770 SS. Mata kuliah ini sangat penting bagi mahasiswa, mengingat untuk lulus USKP para peserta harus lulus seluruh mata ujian, salah satunya adalah $\mathrm{PPh}$ OP. 
Ketika Peraturan Pemerintah No. 46 tahun 2013 tentang Pajak Penghasilan atas Penghasilan dari Usaha yang Diterima atau Diperoleh Wajib Pajak yang Memiliki Peredaran Bruto Tertentu yang mulai berlaku pada tanggal 1 Juli 2013 lalu cukup membuat gempar dunia perpajakan termasuk dunia pendidikan di bidang perpajakan. Dengan dikeluarkannya PP tersebut secara otomatis mengubah sistem perpajakan bagi WP OP dan WP Badan. Berbagai cara dilakukan oleh Prodi Perpajakan agar PP No. 46 tahun 2013 ini dapat tersampaikan dengan baik dan benar kepada mahasiswa, seperti memberikan pelatihan dan seminar kepada dosen serta mengundang dosen tamu dari kalangan praktisi sebagai alternatif pembelajaran untuk mengisi mata kuliah inti perpajakan.

Untuk mengetahui apakah mahasiswa puas terhadap proses pembelajaran yang dilakukan oleh dosen, setiap akhir semester mahasiswa diminta untuk mengisi Kuesioner Evaluasi Proses Pembelajaran Kuliah secara online. Hasil Kuesioner Evaluasi Proses Pembelajaran Kuliah untuk mata kuliah PPh OP yang telah diisi oleh mahasiswa angkatan 2013 menunjukkan IPK yang sangat baik sebesar 4.00 untuk dua item penilaian sekaligus, yaitu materi dan ujian kuliah dan juga dosen pengasuh.

Namun, belum ada evaluasi yang dilakukan untuk mengetahui apakah mahasiswa puas terhadap pelaksanaan kuliah dosen tamu PPh OP, dalam hal ini yang dinilai adalah kompetensi dari dosen tamu tersebut. Padahal menurut Oemar Hamalik (2005), pendidikan dikatakan berkualitas bila proses belajar mengajar dapat berjalan dengan lancar, efektif, efisien dan ada interaksi antara komponen komponen yang terkandung dalam sistem pengajaran, yaitu tujuan pendidikan dan pengajaran, peserta didik atau siswa, tenaga kependidikan atau guru, kurikulum, strategi pembelajaran, media pengajaran dan evaluasi pengajaran. Selain itu, kepuasan mahasiswa adalah salah satu hal yang dinilai pada saat penilaian Borang Akreditasi.

Berdasarkan penjelasan di atas, untuk mengetahui adanya pengaruh positif atau negatif dari kompetensi dosen tamu terhadap kepuasan mahasiswa, maka peneliti melakukan penelitian dengan judul "Pengaruh Kompetensi Dosen Tamu terhadap Kepuasan Mahasiswa Prodi Perpajakan Angkatan 2013 Politeknik Ubaya”.

Rumusan masalah yang dapat diambil dari penelitian ini adalah apakah kompetensi dosen tamu $\mathrm{PPh}$ OP dapat meningkatkan kepuasan mahasiswa Prodi Perpajakan Angkatan 2013?

\section{KAJIAN TEORITIS DAN HIPOTESIS}

Menurut Mulyasa (2007: 60) ada 4 dimensi kompetensi terdiri dari kompetensi pedagogik, kompetensi profesional, kompetensi kepribadian dan kompetensi sosial. Kompetensi kompetensi ini sesuai dengan tuntutan undang-undang guru dan dosen. Kompetensi pedagogik adalah pemahaman guru dan Dosen terhadap peserta didik, perancangan dan pelaksanaan pembelajaran, evaluasi hasil belajar, dan pengembangan peserta didik untuk mengaktualisasikan berbagai potensi yang dimilikinya. Kompentensi profesional merupakan penguasaan materi pembelajaran seca- 
ra luas dan mendalam, yang mencakup penguasaan materi kurikulum mata pelajaran di sekolah dan substansi keilmuan yang menaungi materinya, serta penguasaan terhadap stuktur dan metodologi keilmuannya. Kompetensi kepribadian adalah kemampuan personal yang mencerminkan kepribadian yang mantap, stabil, dewasa, arif, dan berwibawa, menjadi teladan bagi peserta didik, dan berakhlak mulia. Sedangkan kompetensi sosial adalah kemampuan guru dan Dosen untuk berkomunikasi dan bergaul secara efektif dengan peserta didik, sesama pendidik, tenaga kependidikan, orang tua/wali peserta didik, dan masyarakat sekitar.

Kepuasan menurut Parasuraman, Zeithaml dan Berry dalam Sahyar (2009) memiliki dimensi seperti tangible (bukti fisik), reliability (kehandalan), responsiveness (daya tanggap), assurance (jaminan), dan empathy (empati).

Hubungan antara kompetensi dan kepuasan adalah kompetensi memiliki pengaruh positif terhadap kepuasan. Hasil penelitian Sahyar (2009) menyebutkan adanya pengaruh yang signifikan antara kompetensi dosen terhadap kepuasan mahasiswa.. Berdasarkan uraian di atas, maka hipotesis untuk penelitian ini adalah kompetensi dosen tamu dapat meningkatkan kepuasan mahasiswa Program Studi Perpajakan Angkatan 2013 Politeknik Ubaya.

\section{METODE PENELITIAN}

Penelitian ini dilakukan di Kampus Politeknik Ubaya pada bulan Juni tahun 2014 dengan populasi penelitian adalah seluruh mahasiswa semester 2 Program Studi Perpajakan Angkatan 2013 yang berjumlah 48 orang. Total sampling merupakan teknik pengambilan sampel yang digunakan dalam penelitian ini karena jumlah populasi kurang dari 100 orang.

Variabel independen untuk penelitian ini adalah kompetensi dosen tamu. Indikator untuk mengukur variabel ini adalah kompetensi profesional dan kompetensi sosial (Mulyasa, dalam Sahyar, 2009, dikembangkan). Sedangkan kepuasan mahasiswa Program Studi Perpajakan Angkatan 2013 sebagai variabel dependen yang diteliti dalam penelitian ini pengukurannya menggunakan indikator tangible, reliability, responsiveness, assurance, dan empathy (Parasuraman, Zeithaml dan Berry, dalam Sahyar, 2009).

Metode pengumpulan data yang digunakan adalah dengan menyebarkan kuesioner kepada seluruh mahasiswa semester 2 Program Studi Perpajakan Angkatan 2013 yang berjumlah 48 orang. Untuk mencapai tujuan yang diingiinkan maka kuesioner disebar pada saat jam istirahat setelah perkuliahan dosen tamu PPh OP selesai. Kuliah dosen tamu $\mathrm{PPh}$ OP diadakan pada hari Selasa tanggal 3 Juni 2014 yang lalu.

Untuk mengukur jawaban dari responden, kuesioner penelitian ini disusun menggunakan 5 skala Likert, yaitu:

1. Sangat Setuju (SS) dengan skor 5

2. Setuju (S) dengan skor 4

3. Kurang Setuju (KS) dengan skor 3

4. Tidak Setuju (TS) dengan skor 2

5. Sangat Tidak Setuju (STS) dengan skor 1

Total kuesioner yang disebar sebanyak 48 kuesioner dan sebanyak 32 kuesioner yang kembali. Menurut Roscoe (1975) yang dikutip Uma 
Sekaran (2006) ukuran sampel lebih dari 30 dan kurang dari 500 adalah tepat untuk kebanyakan penelitian. Dengan begitu, data yang diperoleh dari hasil jawaban kuesioner layak untuk diolah.

Teknik analisis data Partial Least Square (PLS) merupakan teknik analisis data yang digunakan untuk mengolah data yang diperoleh dari hasil jawaban kuesioner yang kembali. Kelebihan dari PLS ini adalah sifatnya prediktif dan dapat mengolah data dengan jumlah sampel relatif sedikit, yaitu 30 sampai dengan 100 sehingga sangat cocok untuk mengolah data dalam penelitian ini.

\section{HASIL DAN PEMBAHASAN}

Data dari hasil kuesioner responden sebelum diolah lebih lanjut pada PLS menghasilkan workspace dengan variabel independen dan variabel independen serta indikator indikatornya yang digambarkan sebagai berikut.

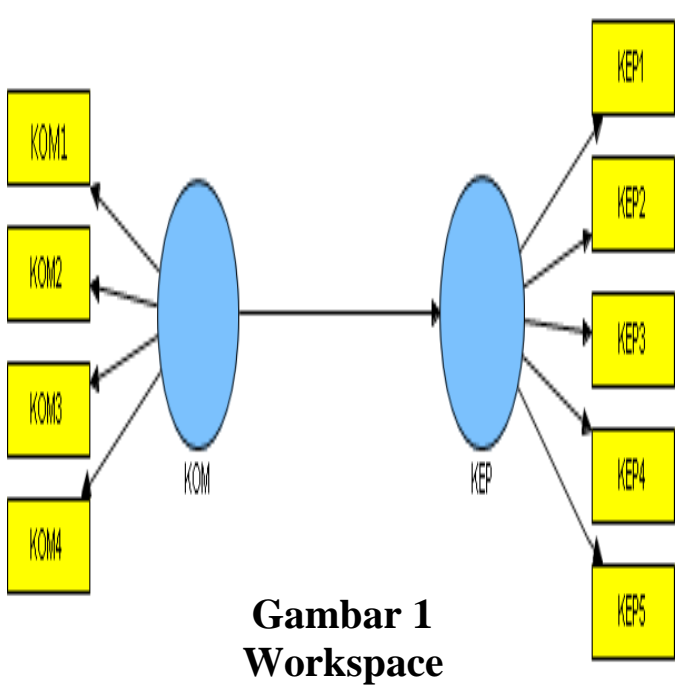

Sumber : Output PLS-Workspace
KOM merupakan variabel independen, yaitu kompetensi dosen tamu. KOM memiliki 4 indikator pengukuran yang dinamakan KOM1, KOM2, KOM3 dan KOM4. Sedangkan KEP adalah variabel dependen, yaitu kepuasan mahasiswa dengan KEP1, KEP2, KEP3, KEP4 dan KEP5 sebagai indikator untuk mengukur kepuasan.

\section{Uji Validitas}

Uji validitas merupakan uji yang dilakukan untuk mengetahui apakah konstruk - konstruk yang terdapat dalam model sudah memenuhi syarat dari sisi validitas dengan cara melihat hasil Outer Loadings dan Average Variant Extracted (AVE). Seluruh indikator harus memiki loading factor di atas 0,5 terhadap konstruk yang dituju sehingga indikator - indikator tersebut dapat dinyatakan valid. Suatu indikator dinyatakan tidak valid jika memiki loading factor di bawah 0,5.

\section{Tabel 1}

Hasil Outer Loadings

\begin{tabular}{|c|c|}
\hline Hubungan & $\begin{array}{c}\text { Outer } \\
\text { Loadings }\end{array}$ \\
\hline KOM1 => KOM & 0,9382 \\
\hline KOM2 => KOM & 0,8133 \\
\hline KOM3 => KOM & 0,9141 \\
\hline KOM4 => KOM & 0,9382 \\
\hline KEP1 => KEP & 0,8487 \\
\hline KEP2 => KEP & 0,8020 \\
\hline KEP3 => KEP & 0,8020 \\
\hline KEP4 => KEP & 0,6718 \\
\hline KEP5 => KEP & 0,7490 \\
\hline Sumber : Output & PLS-Algorithm \\
SmartPLS
\end{tabular}


Tabel 2

Nilai Average Variant Extracted (AVE)

\begin{tabular}{|c|c|}
\hline & AVE \\
\hline KOM & 0,8144 \\
\hline KEP & 0,6038 \\
\hline
\end{tabular}

Sumber : Output PLS-Algorithm SmartPLS

Berdasarkan hasil Outer Loadings dan Average Variant Extracted (AVE) di atas, seluruh indikator harus memiki loading factor di atas 0,5 terhadap konstruk yang dituju sehingga indikator - indikator tersebut dapat dinyatakan valid.

\section{Uji Reabilitas}

Uji reabilitas merupakan uji yang dilakukan untuk mengetahui apakah konstruk yang terdapat pada model penelitian memenuhi kriteria discriminant validity atau menunjukkan nilai lebih besar dari 0,7 pada hasil Composite Reliability dan Cronbachs Alpha.

Tabel 3

Nilai Composite Reliability

\begin{tabular}{|c|c|}
\hline & $\begin{array}{c}\text { Composite } \\
\text { Reliability }\end{array}$ \\
\hline KOM & 0,9459 \\
\hline KEP & 0,9459 \\
\hline
\end{tabular}

Sumber : Output PLS-Algorithm SmartPLS

Tabel 4

Nilai Cronbachs Alpha

\begin{tabular}{|c|c|}
\hline & $\begin{array}{c}\text { Cronbachs } \\
\text { Alpha }\end{array}$ \\
\hline KOM & 0,9228 \\
\hline KEP & 0,8360 \\
\hline
\end{tabular}

Sumber : Output PLS-Algorithm SmartPLS
Berdasarkan nilai Composite Reliability dan Cronbachs Alpha di atas, keduanya menunjukkan nilai yang lebih besar dari 0,7 untuk semua konstruk sehingga semua konstruk memenuhi kriteria discriminant validity.

\section{Pengujian Model Struktural}

Pengujian model struktural dilakukan dengan menggunakan pengujian $R$-Square. Pengujian ini untuk mengetahui besarnya pengaruh variabel independen terhadap variabel dependen secara simultan.

Tabel 5

Output Nilai $R$-Square

\begin{tabular}{|c|c|}
\hline & R-Square \\
\hline KOM & 0,0000 \\
\hline KEP & 0,7821 \\
\hline
\end{tabular}

Sumber : Output PLS-Algorithm SmartPLS

Tabel 5 di atas menunjukkan bahwa kompetensi dosen tamu (KOM) mampu menjelaskan variasi perubahan kepuasan mahasiswa (KEP) sebesar 0.7821 atau $78,21 \%$, sisanya sebesar 0.2179 atau $21,79 \%$ dipengaruhi oleh variabel lain yang tidak termasuk dalam model.

\section{Uji Hipotesis}

Uji hipotesis dalam penelitian ini menggunakan prosedur Bootstrapping yang standar sehingga dapat diketahui apakah hipotesis yang diajukan dalam penelitian ini terbukti atau tidak kebenarannya. Jika nilai T-Statistic yang memiliki nilai di atas 1,96 maka hipotesis diterima. 
Tabel 6

Output Nilai T-Statistic dan Original Sample Estimate

\begin{tabular}{|c|c|c|c|c|c|c|}
\hline & $\mathbf{O}$ & $\mathbf{M}$ & $\begin{array}{c}\mathbf{S T} \\
\mathbf{D E} \\
\mathbf{V}\end{array}$ & $\begin{array}{c}\boldsymbol{S} \boldsymbol{E} \boldsymbol{E} \\
\boldsymbol{R}\end{array}$ & $\begin{array}{c}\mid \mathbf{O} / \\
\boldsymbol{S T} \\
\boldsymbol{E R} \\
\boldsymbol{R}\end{array}$ & Result \\
\hline KOM -> KEP & 0,8 & 0,8 & 0,0 & 0,01 & $\begin{array}{c}65, \\
949 \\
3\end{array}$ & Diterima \\
& 844 & 870 & 134 & 34 & 3 & \\
\hline
\end{tabular}

Sumber : Output Bootstrapping

SmartPLS

Berdasarkan hasil Output Nilai TStatistic dan Original Sample Estimate di atas menunjukkan bahwa Original Sample (O) sebesar 0,8844; Sample Mean (M) sebesar 0,8870; Standard Deviation (STDEV) sebesar 0,0134 dan Standard Error (STERR) sebesar 0,0134. Sedangkan nilai T-Statistic $(|O / S T E R R|)$ KOM $\rightarrow$ KEP sebesar 65,9493 atau di atas 1,96 sehingga Uji Hipotesis diterima, maka kompetensi dosen tamu terbukti dapat meningkatkan kepuasan mahasiswa Prodi Perpajakan Angkatan 2013 Politeknik Ubaya.

\section{KESIMPULAN}

Kesimpulan yang dapat ditarik dari hasil dan pembahasan penelitian ini adalah kompetensi dosen tamu memiliki kontribusi terhadap peningkatan kepuasan mahasiswa Program Studi Perpajakan Angkatan 2013 Politeknik Ubaya. Semakin tinggi kompetensi dosen tamu maka semakin tinggi pula kepuasan mahasiswa.

\section{SARAN}

Oleh karena itu, hendaknya Program Studi Perpajakan mengadakan kuliah dosen tamu secara rutin dan diisi oleh pihak-pihak yang memiliki kompetensi yang tinggi, baik kompetensi profesional maupun kompetensi sosialnya. Selain itu, evaluasi terhadap dosen tamu sangat diperlukan untuk mengetahui tingkat kepuasan maha- siswa, akan lebih baik jika evaluasi diperluas lagi untuk kompetensi pedagogik dan kompetensi kepribadian dari dosen tamu yang mengajar.

\section{DAFTAR KEPUSTAKAAN}

Ghozali, Imam, 2008, Structural Equation Modeling Metode Alternatif dengan Partial Least Square, Badan Penerbit Universitas Diponegoro, Semarang.

Hamalik, Oemar, 2003, Proses Belajar Mengajar, PT Bumi Aksara, Jakarta. 2005, Kurikulum dan Pembelajaran, PT Bumi Aksara, Jakarta.

Keputusan Menteri Keuangan Republik Indonesia Nomor 485/KMK.03/ 2003 tentang Konsultan Pajak Indonesia.

Mulyasa, E., 2007, Menjadi Guru Profesional Menciptakan Pembelajaran Kreatif dan Menyenangkan, Rosdakarya, Bandung.

Peraturan Menteri Keuangan Republik Indonesia Nomor 111/PMK.03/ 2014 tentang Konsultan Pajak.

Peraturan Menteri Pendidikan Republik Indonesia Nomor 16 Tahun 2007 tentang Standar Kualifikasi Akademik dan Kompetensi Guru.

Peraturan Pemerintah Republik Indonesia Nomor 46 Tahun 2013 tentang Pajak Penghasilan atas Penghasilan dari Usaha yang Diterima atau Diperoleh Wajib Pajak yang Memiliki Peredaran Bruto Tertentu. 
Peraturan Pemerintah Republik Indonesia Nomor 4 Tahun 2014 tentang Penyelenggaraan Pendidikan Tinggi dan Pengelolaan Perguruan Tinggi.

Sahyar, 2009, Pengaruh Kompetensi Dosen dan Proses Pembelajaran terhadap Kepuasan Mahasiswa, Pekbis Jurnal, Vol.1, No.3, November, hal. 131-139. 